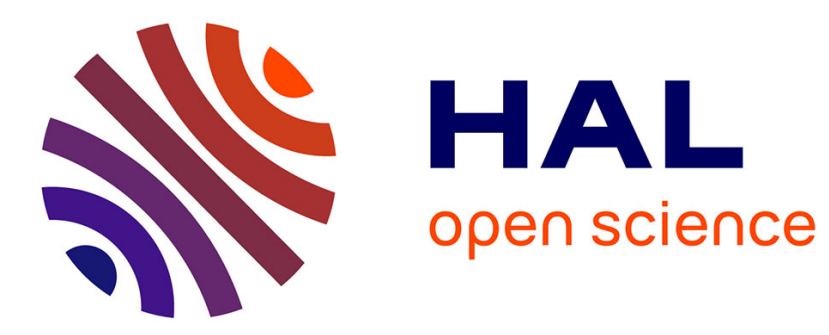

\title{
Food nanotechnology: water is the key to lowering the energy density of processed foods.
}

\author{
Anthony A Robson
}

\section{To cite this version:}

Anthony A Robson. Food nanotechnology: water is the key to lowering the energy density of processed foods.. Nutrition and Health, 2011, 20 (3-4), pp.231-6. 10.1177/026010601102000406 . hal-00637292

\section{HAL Id: hal-00637292 \\ https://hal.univ-brest.fr/hal-00637292}

Submitted on 31 Oct 2011

HAL is a multi-disciplinary open access archive for the deposit and dissemination of scientific research documents, whether they are published or not. The documents may come from teaching and research institutions in France or abroad, or from public or private research centers.
L'archive ouverte pluridisciplinaire HAL, est destinée au dépôt et à la diffusion de documents scientifiques de niveau recherche, publiés ou non, émanant des établissements d'enseignement et de recherche français ou étrangers, des laboratoires publics ou privés. 


\title{
FOOD NANOTECHNOLOGY: WATER IS THE KEY TO LOWERING THE ENERGY DENSITY OF PROCESSED FOODS
}

\author{
AA. ROBSON \\ IUEM (UMR CNRS 6539), Université de Bretagne Occidentale, \\ Technopôle Brest-Iroise, Place Nicolas Copernic, 29280 Plouzané, France
}

\begin{abstract}
It is crucial that emergent technologies create foods that help prevent the causal mechanisms of the diet induced disease epidemic. Food nanotechnology could create modern convenience foods that mimic and improve on the nutritional value of the most nutritious cooked wild foods for humans. Structuring a solid processed food similar to a celery stalk using selfassembled, water-filled, edible nanocells or nanotubes would substantially lower its energy density $\left(<1.6 \mathrm{kcal} \mathrm{g}^{-1}\right)$. Food technologists could harness the natural turgor force to produce a firm chocolate bar, biscuit or breakfast cereal with a good bite, without altering the appearance or taste of the product. Water carries flavour with few calories, and taste sensation per mouthful could be improved by processing food on the nanoscale to increase the surface area that is in contact with taste and smell receptors. The bioavailable nutrient content (including cofactors) of processed foods could be increased by existing bioactive nanoencapsulation. This would allow people to continue to consume modern convenience food on a mass scale, while simultaneously and significantly increasing nutrient intake and reducing energy intake per day. Thus, helping to reduce mental ill health, obesity and other postprandial insults
\end{abstract}

Key words: nanotechnology, self-assemble, molecular recognition, nanocells, nanotubes, diet, disease, water, obesity, food, energy, nutrition

High energy density and low nutrient density which characterise the modern diet must be overcome simultaneously. Overweight and obese people can develop paradoxical nutritional deficiency from eating high energy dense foods with a poor nutrient content. The finding that people with a low energy dense diet $\left(<1.6 \mathrm{kcal} \mathrm{g}^{-1}\right)$ have the lowest total intakes of energy, even though they consume the greatest amount of food has important implications for promoting compliance with a healthy diet (Ledikwe et al. 2006). A processed food which is not both low energy dense and high nutrient dense dilutes the diet of the low energy dense foods of high nutrient density that humans should eat: the most nutritious cooked wild plant and

Email: a.a.robson@hotmail.com. Current address: Ardtoe Marine Laboratory, Ardtoe, Acharacle, Argyll, PH36 4LD, Scotland. Tel: +447969 477327 
animal foods for humans (e.g. Robson 2006; Marean et al. 2007; Robson 2009; Eaton et al. 2010; Robson 2010; Wang et al. 2010). Many foods consumers may consider natural are not due to agriculture, animal husbandry and food processing. Furthermore, the focus on just reducing dietary fat e.g. Farhang (2007) and Hsieh and Ofori (2007), must be refocused on reducing the imbalance between the intake and the expenditure of energy. Cereals $-\mathrm{a}$ food group humans are not yet fully adapted to provides $56 \%$ of humanity's food energy (Cordain 1999) and low fat, high carbohydrate cereal based products are often of high energy density $\left(>2 \mathrm{kcal} \mathrm{g}^{-1}-\right.$ see Ledikwe et al. 2006). For example a Masterfoods Twix ${ }^{\circledR}$ chocolate biscuit bar $(56 \%$ carbohydrate) is $2.2 \%$ water $=5.5 \mathrm{kcal} \mathrm{g}^{-1}$, Kellogg's Special $\mathrm{K}^{\circledR}(71 \%$ carbohydrate) is $3 \%$ water $=3.8 \mathrm{kcal} \mathrm{g}^{-1}$, white bread ( $51 \%$ carbohydrate) is $36 \%$ water $=2.7 \mathrm{kcal} \mathrm{g}^{-1}$, while roasted chicken meat from Cornish game hens $\left(0 \%\right.$ carbohydrate) is $72 \%$ water $=1.3 \mathrm{kcal} \mathrm{g}^{-1}$, shrimp cooked in moist heat $(0 \%$ carbohydrate $)$ is $77 \%$ water $=1.0 \mathrm{kcal} \mathrm{g}^{-1}$ and boiled celery $(4 \%$ carbohydrate) is $94 \%$ water $=0.2 \mathrm{kcal} \mathrm{g}^{-1}$ (c.f. Table 1 and Figure 1).

Molecular recognition is biology's building strategy and key to nanotechnology: biomolecules e.g. self-assembled, water-filled, edible nanocells and nanotubes that self-organise into more complex structures (Graveland-Bikker and De Kruif 2006). Using molecular recognition

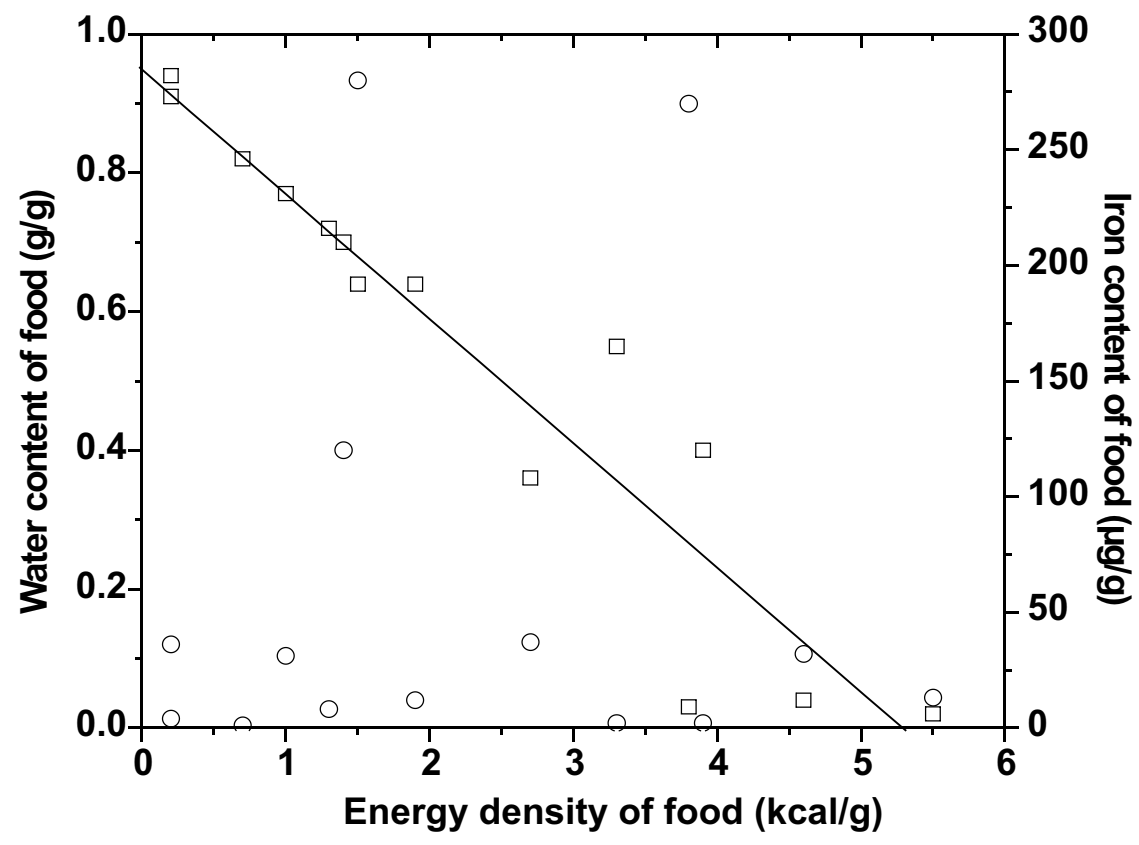

Figure 1. The significant relationship between the energy density of food and its water content (denoted by squares) using data from Table 1 (best-fit regression line: $\mathrm{y}=-0.180 \mathrm{x}+0.949$, $\mathrm{F}_{1,12}=102.0, \mathrm{P}<0.001, \mathrm{R}^{2}=0.9$ ). Also using data from Table 1, the lack of relationship between the energy density of food and its iron content (denoted by circles, $\mathrm{P}=0.895$ ). 
TABLE 1

Energy, water and iron content of a selection of foods

\begin{tabular}{lccc}
\hline & Energy $(\mathrm{kcal} / \mathrm{g})$ & Water $(\mathrm{g} / \mathrm{g})$ & Iron $^{1}(\mu \mathrm{g} / \mathrm{g})$ \\
\hline Masterfoods Twix ${ }^{\circledR}$ bar (42183) & 5.5 & 0.02 & 13 \\
Oat breakfast bar (43100) & 4.6 & 0.04 & 32 \\
Regular mayonnaise (04018) & 3.9 & 0.4 & 2 \\
Kellogg's Special K ${ }^{\circledR}(08067)$ & 3.8 & 0.03 & $270^{*}$ \\
Light mayonnaise (04011) & 3.3 & 0.55 & 2 \\
White bread (18069) & 2.7 & 0.36 & 37 \\
Roasted chicken meat (05013) & 1.9 & 0.6 & 12 \\
Cooked clams (15159) & 1.5 & 0.64 & $280 \infty$ \\
Cooked wild eastern oyster (15169) & 1.4 & 0.70 & $120 \infty$ \\
Roasted meat from Cornish game hens (05310) & 1.3 & 0.72 & 8 \\
Cooked shrimp (15151) & 1.0 & 0.77 & 31 \\
Extra light mayonnaise (04013) & 0.7 & 0.82 & 1 \\
Boiled spinach (11458) & 0.2 & 0.91 & 36 \\
Boiled celery (11144) & 0.2 & 0.94 & 4 \\
\hline
\end{tabular}

Entries retrieved from the USDA National Nutrient Database for Standard Reference, Release 22 (2009) and are identified by a 5-digit nutrient database number in parentheses.

${ }^{1}$ Two billion people, over $30 \%$ of the World's population are anaemic, many due to iron deficiency (World Health Organization 2009).

*fortified with iron, $\infty$ food with a high natural iron content and a low energy density.

processed foods could be created in a more natural, low energy dense way i.e. with high water content. For example, a new and effective way to use molecular recognition would be to structure a chocolate biscuit bar (solid processed food) similar to a celery stalk, to increase its water and fibre content which would substantially lower its energy density $\left(<1.6 \mathrm{kcal} \mathrm{g}^{-1}\right)$. This would allow the same amount of food to feed more people, increasing food security. Celery stalk cells are pressurised with water causing the entire plant to become turgid and stiff. Food technologists could harness this natural turgor force to produce a firm chocolate bar, biscuit or breakfast cereal with a good bite, without altering the appearance or taste of the product. Water carries flavour with few calories e.g. a cup of tea without milk $=0.01 \mathrm{kcal}$ $\mathrm{g}^{-1}$ and taste sensation per mouthful could be improved using the principles of Ultrafine food technology (Eminate Limited, Nottingham, UK); processing food on the nanoscale to increase the surface area that is in contact with taste and smell receptors. The bioavailable nutrient content (including cofactors Das 2006; Robson 2009) of processed foods could be increased by existing bioactive nanoencapsulation.

It is important to consider not only the energy content of a diet but also the energetic cost of its assimilation. A reduction in liquid calorie intake has been found to have a stronger effect on weight loss than a reduction in solid calorie intake (Chen et al. 2009). Sugar sweetened beverages (SSBs) require little digestion. Glucose and fructose can be directly absorbed 
into the bloodstream without digestion. Functional foods are required to simultaneously satisfy the 'sweet tooth' that the modern diet has created, and have a significantly higher energetic assimilation cost compared to today's sugar sweetened foods. This could be achieved by adding protein and fibre to e.g. SSBs, honey, syrup, jam, cereal products and ice cream (Table 2). Protein has more than three times the thermic effect of either fat or carbohydrate (Crovetti et al. 1998) and because it has a greater satiety value than fat or carbohydrate (Crovetti et al. 1998; Stubbs 1998), increased dietary protein is an effective weight-loss strategy for the overweight or obese. Calorie-restricted high-protein diets are more effective than calorierestricted high-carbohydrate diets in promoting (Baba et al. 1999; Skov et al. 1999; Layman 2003) and maintaining (Westerterp-Plantenga et al. 2004) weight loss in overweight subjects while producing less hunger and more satisfaction (Johnston et al. 2004). Furthermore, high protein diets have been shown to improve metabolic control in patients with type 2 diabetes (Seino et al. 1983; Odea 1984; Odea et al. 1989). Some protein based nanotubes are food-grade materials (Graveland-Bikker and De Kruif 2006) and could increase protein consumption at the expense of lowered carbohydrate.

Cooking has obvious beneficial effects by increasing food safety and improving diet quality (Carmody and Wrangham 2009). However, cooking can reduce the water content of a high energy dense processed food. Thus, further increase its deleteriously high energy density, especially if it is cooked twice. For example, toasting whole-wheat bread increases its energy density from $2.5 \mathrm{kcal} \mathrm{g}^{-1}$ to $3.1 \mathrm{kcal} \mathrm{g}^{-1}$ as water content decreases by $14 \%$ (data calculated from USDA National Nutrient Database for Standard Reference). Nanoscale science and technology are now enabling us to understand many

TABLE 2

Sugar, protein and fibre content of a selection of sweet foods and drinks

\begin{tabular}{lccr}
\hline & $\begin{array}{c}\text { Sugar } \\
(\mathrm{g} / 100 \mathrm{~g})\end{array}$ & $\begin{array}{c}\text { Protein } \\
(\mathrm{g} / 100 \mathrm{~g})\end{array}$ & $\begin{array}{c}\text { Fibre } \\
(\mathrm{g} / 100 \mathrm{~g})\end{array}$ \\
\hline Granulated sugar (19335) & 99.8 & 0.0 & 0.0 \\
Brown sugar (19334) & 97.0 & 0.1 & 0.0 \\
Honey (19296) & 82.1 & 0.3 & 0 \\
Boiled sweets (19107) & 62.9 & 0.0 & 0.0 \\
Maple syrup (19353) & 59.5 & 0.0 & 0.0 \\
Apricot preserve (19719) & 43.4 & 0.7 & 0.3 \\
Kellogg's frosted flakes ${ }^{\circledR}(08069)$ & 38.7 & 4.3 & 0.0 \\
High fructose corn syrup (19351) & 26.4 & 0.0 & 0.0 \\
Vanilla ice cream (19089) & 20.7 & 3.5 & 0.0 \\
Cola drink (14148) & 10.6 & 0.0 & 0.0 \\
Red Bull® drink (14154) & 10.1 & 0.3 & \\
\hline
\end{tabular}

Entries retrieved from the USDA National Nutrient Database for Standard Reference, Release 22 (2009) and are identified by a 5-digit nutrient database number in parentheses. 
natural and unnatural processes. Studying nanostructures at the cell and DNA level, gives us insight in to the working of these processes and how to manipulate, prevent and/or enhance them for the benefit of mankind. Emergent technologies can and must help correct the food system by creating modern convenience foods on a mass scale that mimic and improve on the nutritional value of the most nutritious cooked wild foods for humans. Thus, helping to reduce mental ill health, obesity and other postprandial insults (Robson 2009; Robson 2010).

\section{REFERENCES}

Baba, N.H., Sawaya, S., Torbay, N., Habbal, Z., Azar, S., Hashim, S.A. (1999). High protein vs high carbohydrate hypoenergetic diet for the treatment of obese hyperinsulinemic subjects. Int J Obes 23, 1202-1206.

Carmody, R.N., Wrangham, R.W. (2009). The energetic significance of cooking. J Hum Evol 57, 379-391.

Chen, L.W., Appel, L.J., Loria, C., Lin, P.H., Champagne, C.M., Elmer, P.J., Ard, J.D., Mitchell, D., Batch, B.C., Svetkey, L.P., Caballero, B. (2009). Reduction in consumption of sugar-sweetened beverages is associated with weight loss: the PREMIER trial. Am J Clin Nutr 89, 1299-1306.

Cordain, L. (1999). Cereal grains: Humanity's double-edged sword. World Review of Nutrition and Dietetics; Evolutionary aspects of nutrition and health: Diet, exercise, genetics and chronic disease 19-73.

Crovetti, R., Porrini, M., Santangelo, A., Testolin, G. (1998). The influence of thermic effect of food on satiety. Eur J Clin Nutr 52, 482-488.

Das, U.N. (2006). Essential fatty acids: biochemistry, physiology and pathology. Biotechnol $J$ 1, 420-439.

Eaton, S.B., Konner, M.J., Cordain, L. (2010). Diet-dependent acid load, paleolithic nutrition, and evolutionary health promotion. Am J Clin Nutr 91, 295-297.

Farhang, B. (2007). Nanotechnology and lipids. Lipid Technology 19, 132-135.

Graveland-Bikker, J.F., De Kruif, C.G. (2006). Unique milk protein based nanotubes: food and nanotechnology meet. Trends in Food Science \& Technology 17, 196-203.

Hsieh, Y.H.P., Ofori, J.A. (2007). Innovations in food technology for health. Asia Pac J Clin Nutr S16, 65-73.

Johnston, C.S., Tjonn, S.L., Swan, P.D. (2004). High-protein, low-fat diets are effective for weight loss and favorably alter biomarkers in healthy adults. $J$ Nutr 134, 586-591.

Layman, D.K. (2003). The role of leucine in weight loss diets and glucose homeostasis. $J$ Nutr 133, 261S-267S.

Ledikwe, J.H., Blanck, H.M., Kettel Khan, L., Serdula, M.K., Seymour, J.D., Tohill, B.C., Rolls, B.J. (2006). Dietary energy density is associated with energy intake and weight status in US adults. Am J Clin Nutr 83, 1362-1368.

Marean, C.W., Bar-Matthews, M., Bernatchez, J., Fisher, E., Goldberg, P., Herries, A.I.R., Jacobs, Z., Jerardino, A., Karkanas, P., Minichillo, T., Nilssen, P.J., Thompson, E., Watts, I., Williams, H.M. (2007). Early human use of marine resources and pigment in South Africa during the Middle Pleistocene. Nature 449, 905-908.

Odea, K. (1984). Marked improvement in carbohydrate and lipid-metabolism in diabetic australian aborigines after temporary reversion to traditional lifestyle. Diabetes 33, 596603.

Odea, K., Traianedes, K., Ireland, P., Niall, M., Sadler, J., Hopper, J., Deluise, M. (1989). The effects of diet differing in fat, carbohydrate, and fiber on carbohydrate and lipidmetabolism in type-II diabetes. J Am Diet Assoc 89, 1076-1086. 
Robson, A. (2006). Shellfish view of omega-3 and sustainable fisheries. Nature 444, 1002.

Robson, A.A. (2009). Preventing diet induced disease: bioavailable nutrient-rich, low-energydense diets. Nutr Health 20, 135-166.

Robson, A.A. (2010). Nanotechnologies and food: 1st report of session 2009-10: Vol. 2 Evidence. In House of Lords papers 22-II 2009-10, pp. 336-361. The Stationery Office London.

Seino, Y., Seino, S., Ikeda, M., Matsukura, S., Imura, H. (1983). Beneficial-effects of high protein-diet in treatment of mild diabetes. Human Nutrition-Applied Nutrition 37, 226 230

Skov, A.R., Toubro, S., Ronn, B., Holm, L., Astrup, A. (1999). Randomized trial on protein vs carbohydrate in ad libitum fat reduced diet for the treatment of obesity. Int $J$ Obes $\mathbf{2 3}$, $528-536$.

Stubbs, R.J. (1998). Appetite, feeding behaviour and energy balance in human subjects. Proc Nutr Soc 57, 341-356.

Wang, Y., Lehane, C., Ghebremeskel, K., Crawford, M.A. (2010). Modern organic and broiler chickens sold for human consumption provide more energy from fat than protein. Public Health Nutr 13, 400-408.

Westerterp-Plantenga, M.S., Lejeune, M., Nijs, I., van Ooijen, M., Kovacs, E.M.R. (2004). High protein intake sustains weight maintenance after body weight loss in humans. Int $J$ Obes 28, 57-64.

World Health Organization (2009). Micronutrient deficiencies: Iron deficiency anaemia http:// www.whoont/nitrition/topics/ida/en/print.html. 